\title{
OPEN Rapid in situ quantification of the strobilurin resistance mutation G143A in the wheat pathogen Blumeria graminis f. sp. tritici
}

\author{
Kejal N. Dodhia ${ }^{1}$, Belinda A. Cox ${ }^{2}$, Richard P. Oliver ${ }^{3}$ \& Francisco J. Lopez-Ruiz ${ }^{1 \bowtie}$
}

As the incidence of fungicide resistance in plant pathogens continues to increase, control of diseases and the management of resistance would be greatly aided by rapid diagnostic methods. Quantitative allele-specific PCR (ASqPCR) is an ideal technique for the in-field analysis of fungicide resistance as it can quantify the frequency of mutations in fungicide targets. We have applied this technique to the fungal pathogen Blumeria graminis f. sp. tritici (Bgt), the causal agent of wheat powdery mildew. In Australia, strobilurin-resistant Bgt was first discovered in 2016. Molecular analysis revealed a nucleotide transversion in the cytochrome $b$ (cytb) gene in the cytochrome $b c 1$ enzyme complex, resulting in a substitution of alanine for glycine at position 143 (G143A). We have developed an in-field ASqPCR assay that can quantify both the resistant (A143) and sensitive (G143) cytb alleles down to $1.67 \%$ in host and Bgt DNA mixtures, within 90 min of sample collection. The in situ analysis of samples collected during a survey in Tasmania revealed A143 frequencies ranging between $9-100 \%$. Validation of the analysis with a newly developed laboratory based digital PCR assay found no significant differences between the two methods. We have successfully developed an in-field quantification method, for a strobilurin-resistant allele, by pairing the ASqPCR assay on a lightweight qPCR instrument with a quick DNA extraction method. The deployment of these type of methodologies in the field can contribute to the effective in-season management of fungicide resistance.

One of the major challenges that the agricultural industry faces is the control of fungal crop diseases during the emergence of fungicide resistance ${ }^{1-4}$. The presence of fungicide resistant pathogen populations in a crop, not only results in lower efficacy of chemical control methods but also, lower yields and quality due to increased disease pressure $^{5}$. In addition, unnecessary treatment with inefficacious products would represent an additional cost to the grower and contribute to adverse environmental effects ${ }^{6}$. An optimal approach to combat this would be to determine what chemistries the populations are resistant to and use other, more efficacious chemicals instead ${ }^{2}$.

Many cases of fungicide resistance have been functionally linked to specific genotype changes in target genes $^{4,7,8}$. The detection of these genotypic changes is a valuable complement to the phenotypic screening of suspect pathogen isolates. Phenotypic screening requires the isolation of numerous pure cultures of the pathogen and testing for quantitative growth and/or germination inhibition. Such assays are very demanding of space, resources and time, taking many days or weeks. The potential of screening using genotypic methods has been recognised for more than 25 years ${ }^{9,10}$. A wide range of techniques have been used but all are limited by the need to isolate pure strains of the pathogen and to carry out the analyses in a laboratory environment. As such the minimum time for such an assay is still several days. Therefore, the time-frame within which to spray a fungicide can be lost by the time the samples are sent for analysis to a laboratory and results received. In addition, all the assays whether phenotypic or genotypic, which require the establishment of pure strains would induce a bias as this strain may not be representative of the entire population causing the infection ${ }^{11,12}$.

${ }^{1}$ Centre for Crop and Disease Management, School of Molecular and Life Sciences, Curtin University, Bentley, Perth, WA 6102, Australia. ${ }^{2}$ Faculty of Science and Engineering, Curtin University, Perth, WA 6102, Australia. ${ }^{3}$ Curtin

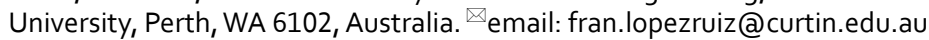


Other methodologies such as loop-mediated isothermal amplification (LAMP) are rapid and can be used with infected plant samples ${ }^{13-15}$. Based on this, LAMP has been used for the successful in-field and laboratory detection of different organisms including chemical resistance in fungi and weeds ${ }^{16-21}$. However, the results from this test are not quantitative and prone to false positives ${ }^{22,23}$.

An ideal solution is an assay which can be performed rapidly, in situ, to quantify the population of fungal pathogens, that are resistant to a given fungicide, with high confidence results. This would prevent the spraying of a fungicide to which a fungus is resistant, as that would both fail to control the disease and increase the selection of fungicide resistant populations ${ }^{24}$. A rapid assay diagnosing the disease, its quantity and fungicide sensitivity status would allow farmers to select the optimum fungicide regime for on-going protection of the crop.

Allele-specific polymerase chain reaction (ASPCR) ${ }^{25}$ is a specific and sensitive assay that was developed for detecting point mutations using PCR followed by gel electrophoresis. This method has been adapted for use with both intercalating dyes and probe-based assays to quantify fungi with genetic changes correlated with fungicide resistance ${ }^{26-28}$. If combined with crude DNA extraction and a 'fast' and robust polymerase that can tolerate field conditions, this assay could be conducted in the field with minimal laboratory equipment.

Blumeria graminis [DC.] E.O. Speer f. sp. tritici Em. Marchal (synonym Erysiphe graminis DC) (Bgt) is an obligate biotrophic pathogen of wheat (Triticum aestivum L.) causing wheat powdery mildew (WPM ${ }^{29}$. Bgt can be controlled with strobilurins [quinone outside inhibitors (QoI)], which target the cytochrome $b c_{1}$ enzyme (cytb) complex, in regions where resistance is not present or at low levels ${ }^{30,31}$. The selection of genotypes resistant to this group of chemicals is facilitated by the combination of Bgt's large population size and its intensive control using fungicides. Strobilurin-resistant genotypes of Bgt were first discovered in 1998 in Germany, just 2 years after their introduction for the control of various crop diseases, and have since been reported in wheat growing regions around the world ${ }^{30,32,33}$. Globally, strobilurins make up $20-25 \%$ of fungicide sales of which azoxystrobin represents a third and is the world's largest selling fungicide ${ }^{34}$. The development of resistance to strobilurins not only threatens effective crop protection, but also reduces the number of mode of actions (MOAs), available to growers, contributing to the increase of fungicide resistance risk on those systems ${ }^{5}$.

Sequencing of the $c y t b$ gene from Bgt showed that a single nucleotide polymorphism (SNP) of a guanidine to cytosine at position $428(\mathrm{~g} 428 \mathrm{c})$, was the only difference between the sensitive and resistant isolates ${ }^{30}$. This mutation results in the amino acid change of glycine to alanine at position 143 (G143A) in the Cytb protein, (homologous to the archetypal G143A mutation in the Cytb of Zymoseptoria tritici) ${ }^{30,35}$. However, due to cytb being a multi-copy mitochondrial gene, it can exhibit heteroplasmy whereby within any given fungal cell, the SNP maybe present only in a few copies within a mitochondrion and/or a few of these organelles ${ }^{36}$. Any fungal cultures with $100 \%$ abundance of the $c y t b$ G143 or A143 allele are referred to as homoplasmic cultures ${ }^{26}$.

In Australia, over $10 \mathrm{Mha}$ are sown with wheat annually, thus providing a large breeding ground for this pathogen ${ }^{37}$. However, due to the range of climatic zones within the Australian wheat belt, mildew infections are most common in areas with medium to high rainfall, as cool humid conditions are required for optimal disease development. In the regions of Australia where WPM is prevalent, it can cause up to $25 \%$ yield losses due to a reduction of photosynthetic leaf area and nutrients available to the crop ${ }^{38}$. The analysis of the cost of WPM to the Australian wheat industry, for production in the 1990s and 2000s, shows that in the absence of control losses of up to AU\$18 million/year can be expected ${ }^{38}$. However, due to control measures these losses are currently at AU\$3 million/year ${ }^{38}$. Of the AU\$15 million in mitigated losses, use of chemical control attributes to one-third (AU\$5 million) of the reduction in potential losses due to mildew ${ }^{38}$. The first report of strobilurin resistance in Australian Bgt, attributed to field failure observations, was from the states of Victoria and Tasmania in $2016^{39}$.

Here we report the development of a quantitative allele-specific PCR (ASqPCR), performed on a portable thermal cycler, which can be powered by a battery, coupled with a simple 2-step DNA extraction protocol. The method successfully generated accurate genotype frequencies of the Bgt Cytb G143A fungicide resistance mutation, on-site, within 90 min of sample collection. To our knowledge, this is the first in situ 'closed tube' allele quantification in a plant pathogen.

\section{Results}

Identification of the G143A mutation in the CytB protein. A 465 bp PCR amplicon of the cytb gene was amplified from one barley powdery mildew and 10 WPM samples, and sequenced as described in the "Materials and methods" (Tables 1 and 2). The alignment of these sequences together with QoI-sensitive and resistant Bgt cytb reference sequences, revealed the presence of the mutation $g 428 c$ (Cytb amino acid substitution G143A) only in the samples which had been collected from paddocks where the use of QoI fungicides had failed to control the disease i.e. two samples each from Tasmania and Victoria (Fig. 1). No mutations in the $c y t b$ gene were found in any of the remaining samples, which agreed with the successful control of WPM with QoI-containing fungicides in the paddocks where these samples had been collected. The analysis of the chromatograms also shows that for the Victorian samples Geelong 1 and 2 there was only a peak for a $\mathrm{C}$ base at the mutation site, whereas for the Tasmanian samples Launceston 1 and 2, there was an additional smaller peak for a G base. All samples analysed from Western Australia and South Australia were wild-type.

dPCR and ASqPCR successfully quantify Bgt cytb g428c.

The dPCR analysis successfully quantified the A143 allele in total DNA from field samples collected in 2016 corroborating the results from the sequencing of the cytb gene (Tables 1 and 3; Fig. 1). To evaluate the accuracy and sensitivity of the assay, genomic DNA from infected leaves with Bgt from Goomalling (100\% G143; QoI sensitive) and Geelong 1 (100\% A143; QoI resistant), were mixed in known allelic ratios and subjected to dPCR analysis. Scatter plot representation of the results showed well-defined, discrete groups of either wild type (G143) or mutant (A143) allele only, both alleles and neither allele present (Fig. 2a). The analysis of the dilution series indicated a high correlation between percentage of A143 allele detected and known G143/A143 allele 


\begin{tabular}{|c|c|c|c|c|}
\hline Year & Town/region, state ${ }^{a}$ & No of samples & Cultivar $^{\mathrm{b}}$ & A143 frequency (\%) \\
\hline \multirow{8}{*}{2016} & Arthur River, WA & 1 & - & 0 \\
\hline & Geraldton, WA & 1 & Wyalkatchem & 0 \\
\hline & Goomalling, WA & 1 & Zen & 0 \\
\hline & Moora, WA & 1 & Corrack & 0 \\
\hline & Neuton, SA & 2 & - & 0 \\
\hline & Launceston, TAS & 1 & Golden Promise $^{\mathrm{d}}$ & 0 \\
\hline & Launceston, TAS & 2 & Mackellar, Forrest & $92.66,93.05$ \\
\hline & Geelong, VIC & 2 & Gazelle & $99.96,99.73$ \\
\hline \multirow{4}{*}{2018} & Table Cape site 1, TAS & 6 & - & $50.51 \pm 22.30$ \\
\hline & Table Cape site 2, TAS & 6 & - & $44.14 \pm 30.17$ \\
\hline & Conara site 1 , TAS & 5 & Manning & $98.05 \pm 2.29$ \\
\hline & Conara site 2 , TAS & 5 & Trojan & $93.39 \pm 6.78$ \\
\hline \multirow{12}{*}{2019} & \multirow{12}{*}{ Northern Yorke Peninsula, SA } & \multirow{12}{*}{12} & Chief & 0 \\
\hline & & & Chief & 0 \\
\hline & & & Trojan & 0 \\
\hline & & & Sceptre & 1.94 \\
\hline & & & Chief & 2.34 \\
\hline & & & - & 3.02 \\
\hline & & & - & 6.67 \\
\hline & & & Chief & 7.22 \\
\hline & & & Sceptre & 27.79 \\
\hline & & & Sceptre & 33.50 \\
\hline & & & Chief & 34.01 \\
\hline & & & Chief & 53.72 \\
\hline
\end{tabular}

Table 1. Sample details and cytb A143 allele frequency of Blumeria graminis f. sp. tritici from infected wheat collected in this study. ${ }^{a}$ WA Western Australia, SA South Australia, TAS Tasmania, VIC Victoria. ${ }^{b}$ Unknown cultivars are denoted as $-{ }^{c}$ All values as per dPCR analysis except the 2019 samples which are from ASqPCR. For 2018 samples, the values represent averages ( \pm s.d.) per site. ${ }^{\mathrm{d} B a r l e y ~ s a m p l e . ~}$

\begin{tabular}{|c|c|c|c|c|c|}
\hline Primer name ${ }^{\mathrm{a}}$ & Sequence $\left(5^{\prime}-3^{\prime}\right)$ & Product size (bp) & $\begin{array}{l}\text { Anneal temperature } \\
\left({ }^{\circ} \mathrm{C}\right)\end{array}$ & Purpose & Source \\
\hline BgCytB_G143A_F & $\begin{array}{l}\text { CTGCATTCCTGG } \\
\text { GTTATGTATTGC }\end{array}$ & \multirow[b]{2}{*}{86} & \multirow[b]{2}{*}{ See below } & \multirow[b]{2}{*}{$\mathrm{dPCR} / \mathrm{qPCR}$ primers } & \multirow[b]{2}{*}{ This study } \\
\hline BgCytB_G143A_R & $\begin{array}{l}\text { TGGTATAGCGCT } \\
\text { CATTAGGTTAGT } \\
\text { GA }\end{array}$ & & & & \\
\hline BgCytB_G143A_dP1 & $\begin{array}{l}\text { FAM-CGGTTG } \\
\text { CAGCCCAGT } \\
\text { G-NFQ } \\
\end{array}$ & \multirow[t]{2}{*}{-} & \multirow[t]{2}{*}{58} & \multirow{2}{*}{ dPCR probes } & \multirow{2}{*}{ This study } \\
\hline BgCytB_G143A_dP2 & $\begin{array}{l}\text { VIC-ACGGTTGCA } \\
\text { CCCCAGTG-NFQ }\end{array}$ & & & & \\
\hline BgCytB_G143A_mP1 & $\begin{array}{l}\text { FAM-CGGTTGCA } \\
\text { GCCCAGTG-BHQ1 }\end{array}$ & \multirow[b]{2}{*}{-} & \multirow{2}{*}{67} & \multirow{2}{*}{ qPCR probes } & \multirow{2}{*}{ This study } \\
\hline BgCytB_G143A_mP2 & $\begin{array}{l}\text { HEX-ACGGTTGCA } \\
\text { CCCCAGTG-BHQ1 }\end{array}$ & & & & \\
\hline WM-Cb-f & $\begin{array}{l}\text { GCGGGATGTTAA } \\
\text { TAACGGATGAT }\end{array}$ & \multirow{2}{*}{465} & \multirow{2}{*}{55} & \multirow{2}{*}{ Sequencing primers } & \multirow{2}{*}{ Bäumler et al. (2003) } \\
\hline WM-Cb-R & $\begin{array}{l}\text { GGAGCCATAGGT } \\
\text { AATCTATCG }\end{array}$ & & & & \\
\hline
\end{tabular}

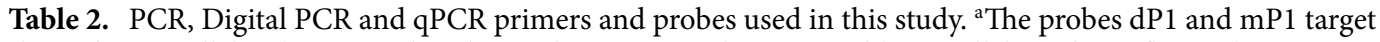
the cytb A143 allele whereas probes $\mathrm{dP} 2$ and mP2 target the G143 wild-type allele. Italics-fluorophore/ quencher; bold-single nucleotide polymorphism; underlined-locked nucleic acid.

ratios $\left(\mathrm{R}^{2}=0.999\right)$, with the lower level of quantification of the mutant allele determined to be $0.33 \%$, and the allele detectable at $0.07 \%$ (Table 4; Supplementary Fig. S1). No cross-reaction was found when genomic DNA from other common wheat pathogens was tested, however, the closely related barley powdery mildew pathogen Blumeria graminis f. sp. hordei was positive for the G143 allele (Table 3). 


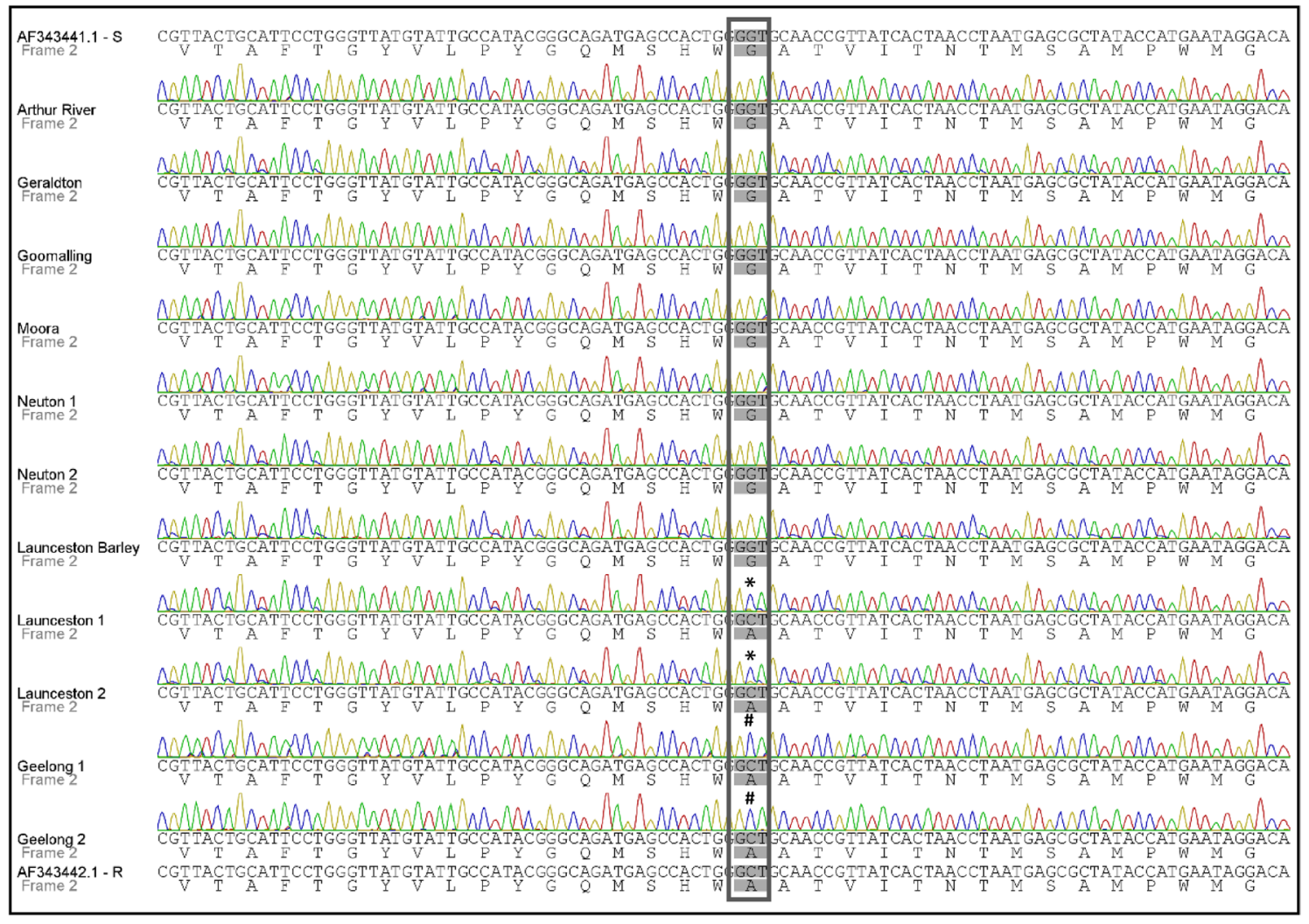

Figure 1. Multiple sequence alignment of the $c y t b$ gene sequence and its translation (yeast mitochondrial translation table_3) flanking the $g 428 \mathrm{c}$ mutation for samples collected in 2016 (Table 1). AF343441.1 and AF343442.1 correspond to strobilurin sensitive and resistant Bgt cytb reference sequences, respectively. The samples Launceston 1 and 2, and Geelong 1 and 2 contain the substitution G143A. Codon 143 is boxed; * denotes a mix of the G and C base; \# shows C base only. Arthur River, Geraldton, Goomalling and MooraWestern Australia; Neuton-South Australia; Launceston-Tasmania; Geelong-Victoria.

\begin{tabular}{|c|c|c|c|c|c|c|}
\hline DNA sample ${ }^{a}$ & $\% \mathrm{~A} 143$ & CI \% A143 & Copies $\mu L^{-1}$ G143 & $\begin{array}{l}\text { CI copies } \mu \mathrm{L}^{-1} \\
\text { G143 }\end{array}$ & Copies $\mu \mathrm{L}^{-1}$ A143 & $\begin{array}{l}\text { CI copies } \mu \mathrm{L}^{-1} \\
\text { A143 }\end{array}$ \\
\hline Arthur river, WA & 0 & - & 3231 & $3165.80-3297.60$ & 0 & - \\
\hline Moora, WA & 0.04 & $1.59 \mathrm{E}-2-7.75 \mathrm{E}-2$ & 1275.50 & $1250.70-1300.80$ & 0.45 & $0.20-1.01$ \\
\hline Geraldton, WA & 0.02 & $5.17 \mathrm{E}-3-7.08 \mathrm{E}-2$ & 826.48 & $807.76-845.63$ & 0.16 & $4.01 \mathrm{E}-2-0.64$ \\
\hline Goomalling, WA & 0 & - & 1524.60 & $1495.90-1553.70$ & 0 & - \\
\hline Neuton 1, SA & 0 & - & 401.88 & $389.95-414.18$ & 0 & - \\
\hline Neuton 2, SA & 0.01 & $2.50 \mathrm{E}-3-8.30 \mathrm{E}-2$ & 530.47 & $516.65-544.67$ & $7.77 \mathrm{E}-02$ & $1.09 \mathrm{E}-2-0.55$ \\
\hline Launceston 1, Tas & 92.66 & \begin{tabular}{|l|}
$88.80-96.56$ \\
\end{tabular} & 94.07 & \begin{tabular}{|l|}
$88.90-99.54$ \\
\end{tabular} & 1187.30 & $1163.80-1211.40$ \\
\hline Launceston 2, Tas & 93.05 & \begin{tabular}{|l|}
$89.06-97.12$ \\
\end{tabular} & 50.08 & $46.32-54.15$ & 670.21 & $654.18-686.64$ \\
\hline Geelong 1, Vic & 99.96 & 95.74-104.24 & 0.42 & $0.17-1.00$ & 1170.10 & $1145.60-1195.20$ \\
\hline Geelong 2, Vic & 99.73 & 94.51-105.16 & 0.80 & $0.43-1.49$ & 300.65 & 290.60-311.05 \\
\hline $\begin{array}{l}\text { Blumeria graminis } \mathrm{f} \text {. } \\
\text { sp. hordei }\end{array}$ & 0 & - & 7547.60 & $7214.10-7896.60$ & 0 & - \\
\hline $\begin{array}{l}\text { Parastagonospora } \\
\text { nodorum }^{\mathrm{c}}\end{array}$ & 6.64 & $1.12-39.51$ & 1.36 & $0.80-2.29$ & $9.68 \mathrm{E}-02$ & $1.36 \mathrm{E}-2-0.69$ \\
\hline Wheat leaf rust ${ }^{c}$ & 23.02 & $10.77-48.40$ & 2.14 & $1.47-3.13$ & 0.64 & $0.32-1.27$ \\
\hline $\begin{array}{l}\text { Wheat leaf (unin- } \\
\text { fected) }^{c}\end{array}$ & 74.29 & $18.75-299.31$ & 0.09 & $1.24 \mathrm{E}-2-0.62$ & 0.26 & $8.51 \mathrm{E}-2-0.82$ \\
\hline Water $^{\mathrm{c}}$ & 50 & $6.53-381.59$ & $7.37 \mathrm{E}-02$ & $1.04 \mathrm{E}-2-0.52$ & $7.37 \mathrm{E}-02$ & $1.04 \mathrm{E}-2-0.52$ \\
\hline
\end{tabular}

Table 3. Specificity of detection of the G143A dPCR assay on total DNA from Blumeria graminis f. sp. tritici infected wheat leaf field samples and controls. ${ }^{a} W A$ Western Australia, SA South Australia, Tas Tasmania, Vic

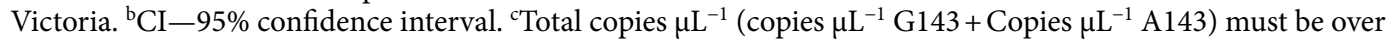
200 for a valid result. 

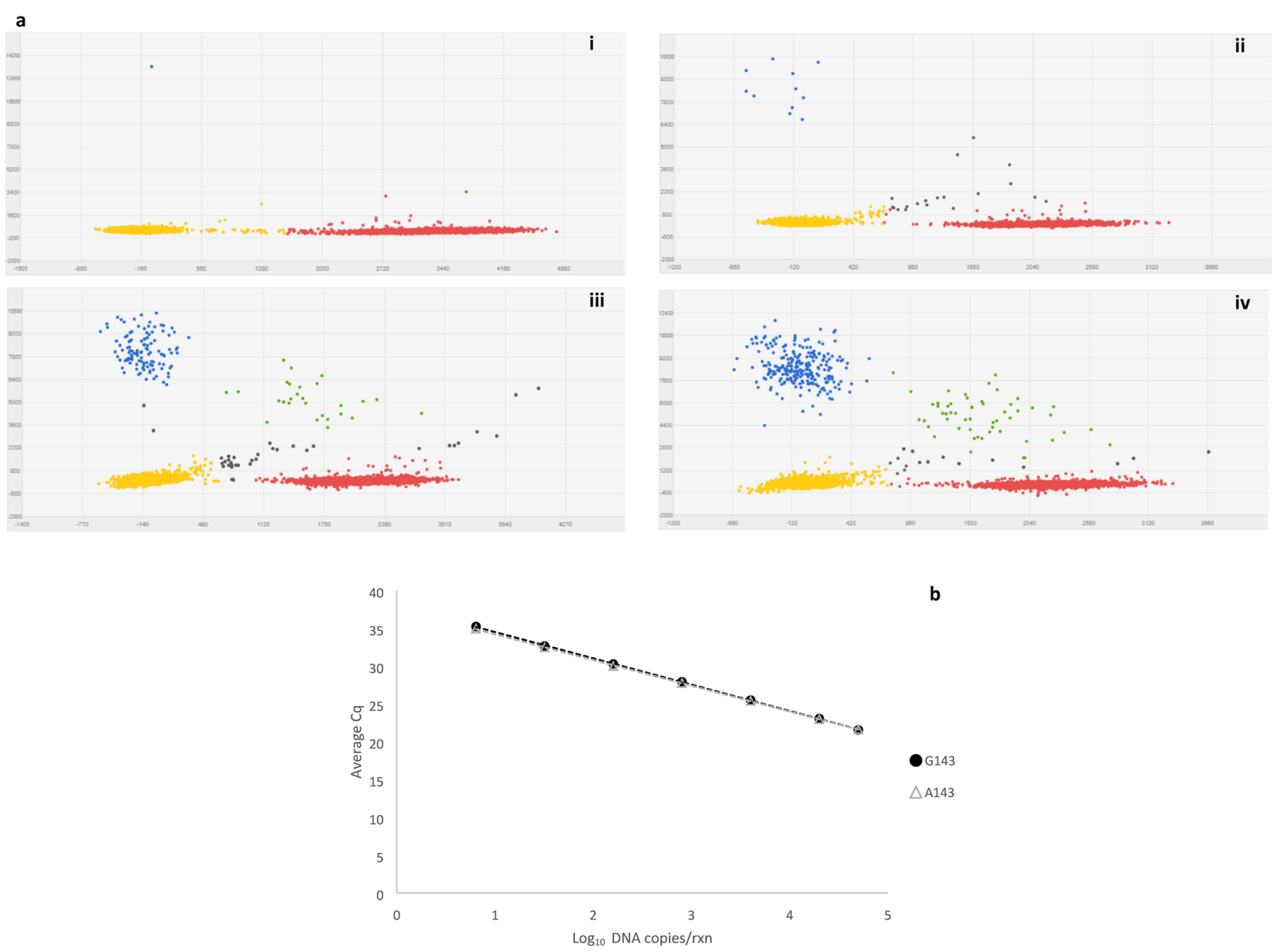

Figure 2. Sensitivity and specificity of the dPCR and ASqPCR assays targeting the $c y t b$ G143A. (a) Scatter plots for Blumeria graminis f. sp tritici (Bgt) G143A dPCR assay using known ratios of genomic DNA for the strobilurin resistant Bgt sample Geelong 1 (A143 allele) and sensitive Bgt sample Goomalling (G143 allele). Scatter plots were prepared with Quantstudio 3D AnalysisSuite. Wells with the A143 allele are represented by blue signals (FAM), G143 alleles are represented by red signals (VIC), detection of both alleles are represented by green signals, wells without any alleles (passive reference) are represented by yellow signals (ROX) and outliers represented by grey signals. (i) $100 \%$ Goomalling gDNA (G143 allele only); A143 frequency $=0.04 \%$. (ii) $0.33 \%$ Geelong1 gDNA; A143 frequency $=0.23 \%$. (iii) $3.39 \%$ Geelong 1 gDNA; A143 frequency $=3.10 \%$. (iv) $6.90 \%$ Geelong 1 gDNA; A143 frequency $=7.87 \%$. (b) Correlation of threshold cycle in ASqPCR and amount of DNA of either G143 $\left(\mathrm{R}^{2}=0.9998\right)$ or A143 $\left(\mathrm{R}^{2}=0.9999\right)$ alleles, respectively.

The assay identified very high frequencies of the A143 allele in locations where QoI control failure had previously been reported (Tables 1 and 3). Where QoIs controlled the disease satisfactorily, the frequency of the A143 allele remained below the assay detection level. The double peaks observed in the sequencing chromatograms of samples Launceston 1 and 2 were in agreement with the A143 allele frequencies determined by the dPCR assay (92.66 and 93.05\%, respectively). In a similar manner, samples Geelong 1 and 2 showed A143 frequencies of virtually $100 \%$, which correlated with the single peaks observed in the chromatograms of these two samples (Fig. 1; Table 3).

The SensiFast Probe No-Rox master mix was considered the most suitable for ASqPCR with crude DNA samples on a magnetic induction cycler (MIC) qPCR instrument (Bio Molecular Systems, Australia) under field conditions. In the reactions where the iQ multiplex Supermix was used, the G143 allele was detected in both the HEX and FAM channels. In the case of the samples analysed using the Immomix, no amplification was observed from any of the crude DNA extracts (Table 5).

The test for the interassay repeatability showed that the frequency of the A143 allele, for the $51 \%$ A 143 sample, when calculated from the standard curves for both tests had a mean of $52.9 \%(n=16 ; C V=1.2 \%$; variation from theoretical value $=3.7 \%$ ). Subsequent analysis of the dilution series, with ASqPCR showed that the lower level of quantification of the mutant allele in mixture with the wild type was in this case $1.67 \%$ (Table 4; Supplementary Fig. S1). In addition, in homoplasmic reactions, the assay quantified down to seven copies per reaction for both G143 and the A143 alleles (Fig. 2b). As with the dPCR assay, wheat pathogens Parastagonospora nodorum and Pyrenophora tritici-repentis were not detected. The assay however detected the closely related barley mildew $B$. graminis f. sp. hordei, but not the grape mildew Erysiphe necator (data not shown). 


\begin{tabular}{|l|l|l|l|l|}
\hline \multirow{2}{*}{ DNA sample $^{\mathbf{a}}$} & \multicolumn{2}{|l|}{ dPCR } & \multicolumn{2}{l|}{ ASqPCR } \\
\cline { 2 - 5 } \% A143 & CI \% A143 $^{\mathbf{b}}$ & \% A143 & CI \% A143 \\
\hline $100 \%$ Goo & 0.04 & $1.19 \mathrm{E}-2-0.16$ & 0 & - \\
\hline $0.07 \%$ Gee 1 & 0.30 & $0.18-0.51$ & 0 & - \\
\hline $0.17 \%$ Gee 1 & 0.10 & $4.41 \mathrm{E}-2-0.25$ & 0 & - \\
\hline $0.33 \%$ Gee 1 & 0.23 & $0.13-0.42$ & 0 & - \\
\hline $0.67 \%$ Gee 1 & 0.57 & $0.37-0.88$ & 0 & - \\
\hline $1.68 \%$ Gee 1 & 2.01 & $1.63-2.48$ & 1.48 & $1.32-1.64$ \\
\hline $3.39 \%$ Gee 1 & 3.10 & $2.61-3.68$ & 4.06 & $3.82-4.30$ \\
\hline $6.90 \%$ Gee 1 & 7.87 & $6.98-8.87$ & 8.00 & $7.22-8.77$ \\
\hline $18.18 \%$ Gee 1 & 21.72 & $19.98-23.59$ & 20.24 & $19.96-20.51$ \\
\hline $40 \%$ Gee 1 & 38.45 & $36.00-41.04$ & $\mathrm{NA}^{\mathrm{c}}$ & - \\
\hline $66.67 \%$ Gee 1 & 65.15 & $61.41-69.05$ & 68.40 & $67.90-68.89$ \\
\hline $100 \%$ Gee 1 & 99.67 & $94.43-105.11$ & 100 & - \\
\hline
\end{tabular}

Table 4. Sensitivity of the G143A dPCR and ASqPCR assays on a mixture of total DNA of leaves infected with mutant (A143) and wild type (G143) Blumeria graminis f. sp. tritici. ${ }^{a}$ Goo Goomalling (G143), Gee1 Geelong 1 (A143). ${ }^{\mathrm{b}} \mathrm{CI} 95 \%$ confidence interval. ${ }^{\mathrm{c}}$ This concentration was not tested with ASqPCR.

\begin{tabular}{|l|l|l|l|l|l|l|}
\hline & \multicolumn{3}{|l|}{ G143 target (HEX channel) } & \multicolumn{2}{l|}{ A143 target (FAM channel) } \\
\cline { 2 - 7 } & Mix 1 & Mix 2 & Mix 3 & Mix 1 & Mix 2 & Mix 3 \\
\hline $100 \%$ G143 (L) & $19.02 \pm 0.50^{\mathrm{d}}$ & $19.22 \pm 0.50$ & $34.25 \pm 1.21$ & $\mathbf{2 5 . 6 5} \pm \mathbf{0 . 3 4}$ & - & - \\
\hline $100 \% \mathrm{G} 143(\mathrm{Q})^{\mathrm{b}}$ & $23.79 \pm 0.56$ & $24.49 \pm 0.44$ & - & - & - & - \\
\hline $100 \% \mathrm{~A} 143(\mathrm{~L})$ & - & - & - & $18.39 \pm 0.40$ & $18.64 \pm 0.35$ & $32.52 \pm 0.22$ \\
\hline $100 \% \mathrm{~A} 143(\mathrm{Q})$ & - & - & - & $23.43 \pm 0.25$ & $23.89 \pm 0.22$ & - \\
\hline $51 \% \mathrm{~A} 143(\mathrm{~L})^{\mathrm{c}}$ & $23.53 \pm 0.63$ & $23.78 \pm 0.65$ & $38.24 \pm 0.09$ & $21.60 \pm 0.09$ & $21.99 \pm 0.15$ & $36.73 \pm 0.27$ \\
\hline NTC & - & - & - & - & - & - \\
\hline
\end{tabular}

Table 5. Cq values obtained from the assessment of three qPCR mastermixes. Mix 1 (iQ Multiplex Supermix), Mix 2 (Sensifast Probe No-Rox mix) and Mix 3 (Immomix), with total DNA of leaves infected with wild type (G143) and mutant (A143) wheat powdery mildew. Non-target amplification is indicated in bold. ${ }^{a}$ DNA extracted using a standard laboratory method. ${ }^{b} \mathrm{DNA}$ extracted using the quick field extraction method. ${ }^{\mathrm{c}} 49 \%$ G143. ${ }^{\mathrm{d}}$ s.d. (5 replicates).

Optimisation of the in-field allele frequency quantification pipeline. The suitability of the infield Bgt cytb A143 allele quantification method was assessed as part of a two-day field trip across the Northern wheat-growing region of Tasmania (Fig. 3). The ASqPCR assay conducted on the MIC qPCR instrument (Bio Molecular Systems), with crude DNA extracted in the field as described in the "Materials and methods", successfully distinguished between G143 and A143 alleles under field conditions. The resistant genotype could be detected in all of the 22 samples tested across the four collection sites, albeit at varying levels (Fig. 4a).

The largest variation in the frequency of the $c y t b$ mutant allele was observed in the samples collected on day 1. Frequencies of the A143 allele in the Table Cape region ranged from 27.3-86.0\% (average $=52.3 \% \pm 19.7$ ) in the first site (Fig. 4a, 1A-1F) and from 9.0-94.0\% (average $=40.6 \pm 30.7$ ) in the second site (Fig. 4a, 2A-2F). The analysis of the samples collected at the two sites in the Midlands region revealed a higher frequency of the A143 allele, with the majority of the samples showing values above 99\% (average $=98.7 \pm 3.6$ ) (Fig. 4a, 3A-3E and $4 \mathrm{~A}-4 \mathrm{E})$.

In-lab analysis of samples. The second set of powdery mildew infected wheat disc halves was sent by overnight courier and analysed in our laboratory as described earlier. The frequency of the A143 allele in both the APCR and ASqPCR analyses was comparable to the results from the field analysis (Fig. 4a). Samples collected on day 1 had, in general, lower and more variable A143 allele frequencies than those from day 2 . The frequency of the mutant allele in the samples collected from site one was $36.8 \%$ to $85.9 \%$ and $21.8 \%$ to $78.0 \%$ for the dPCR and ASqPCR assays, respectively (Fig. 4a, 1A-1F). For these analyses as well, the largest variation in the A143 frequency was found in the samples from the second site, which had frequencies ranging from 16.9 to $98.6 \%$ for dPCR and 18.9 to $96.8 \%$ for ASqPCR (Fig. 4a, 2A-2F).

As with the in-field analysis, the mutant allele was found at frequencies close to $100 \%$ in the majority of samples collected on day 2. In this case, the frequency of the A143 allele observed ranged from 82.0 to $99.9 \%$ and 84.1 to $100 \%$ for $\mathrm{dPCR}$ and ASqPCR, respectively (Fig. 4a, 3A-4E). No results were obtained when the crude extract, which had been shipped with the set 2 of infected material, was analysed using the dPCR assay (data not shown). 


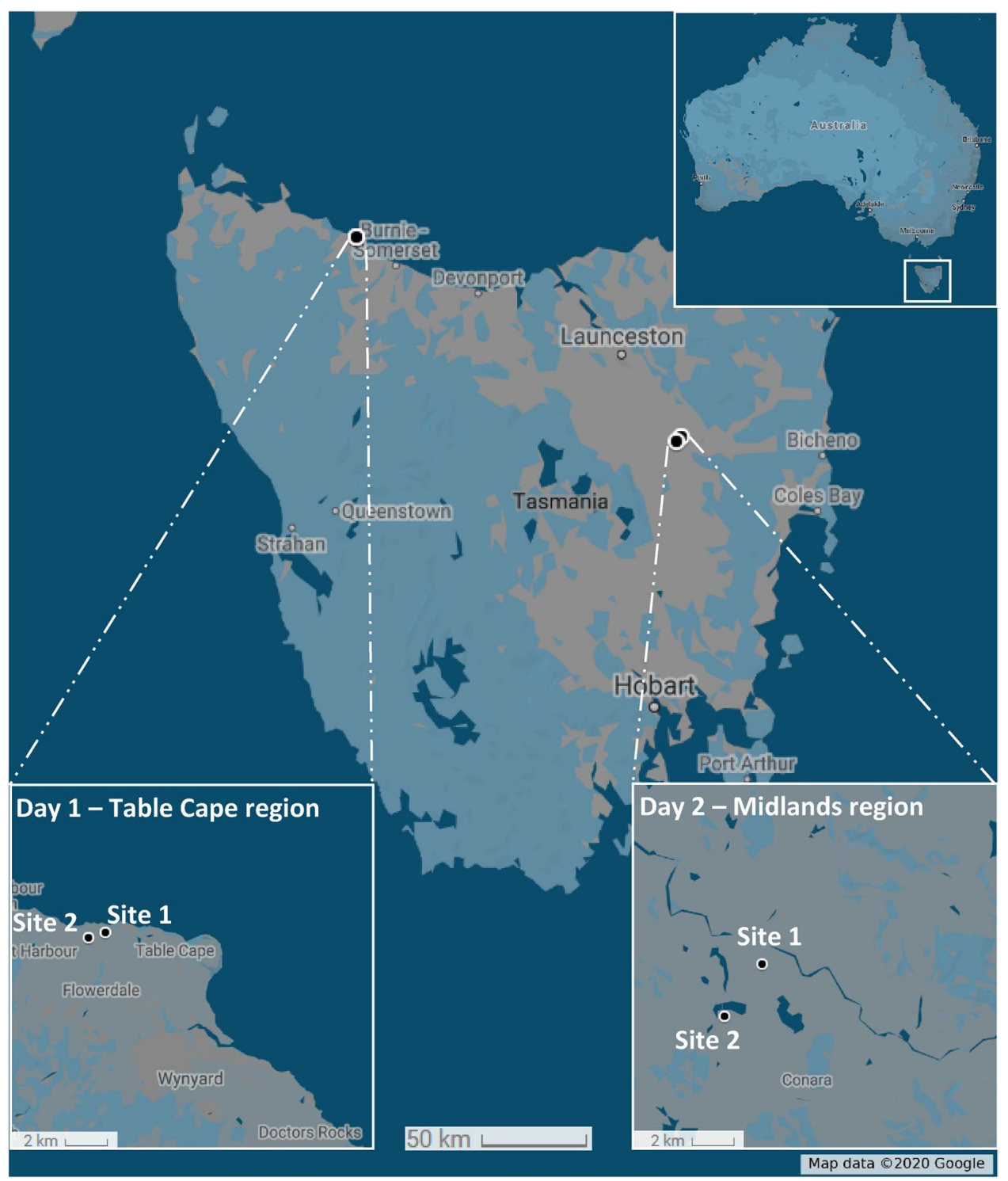

Figure 3. Map showing sampling locations in Tasmania (Australia).

Comparison of test methods. To determine the accuracy of the in-field ASqPCR method, A143 allele frequency data was compared to that from ASqPCR and APCR experiments performed in our laboratory. Paired sample $t$ test analysis showed that the frequency results obtained in the field were not significantly different from those of the same experiment performed in the laboratory using a standard method to extract DNA from the original samples ( $p$ value $=0.190$ ). The same was observed when the A143 allele frequencies from the field analysis were compared to the results obtained with dPCR using DNA extracted in the laboratory ( $p$ value $=0.677$ ). The box plots (Fig. 4b) also showed that the mean and median values of the results for each method were within the interquartile range (IQR) of the other methods, which reinforces the observation that the results are not dissimilar.

The Bland-Altmann analysis also showed a good correlation between the field ASqPCR and the laboratory dPCR methods, with data points distributed about the line of bias (Fig. 5). On average, the A143 allele frequencies calculated using the field ASqPCR were overestimated by $0.86 \%$ (bias), compared to the dPCR results. Twenty out of 22 samples (90.91\%) were within the upper and lower limits of agreement of 19.21 and -17.48, respectively (Fig. 5).

Deployment of the field Bgt cytb G143A ASqPCR. Towards the end of the 2019 growing season, South Australian agronomists were reporting poor control of wheat powdery mildew after treatment with QoI fungicides. The A143 ASqPCR method was showcased as part of an extension activity organised within an industry field day in Bute, Yorke Peninsula (South Australia). A total of 12 symptomatic samples were brought by participants from surrounding wheat fields and analysed on the spot. The frequency of the $c y t b$ A143 allele ranged from 1.9 to $53.7 \%$ (average $=14.2 \pm 17.4 ; \mathrm{n}=9$ samples which showed the presence of the $c y t b$ A143 allele) 


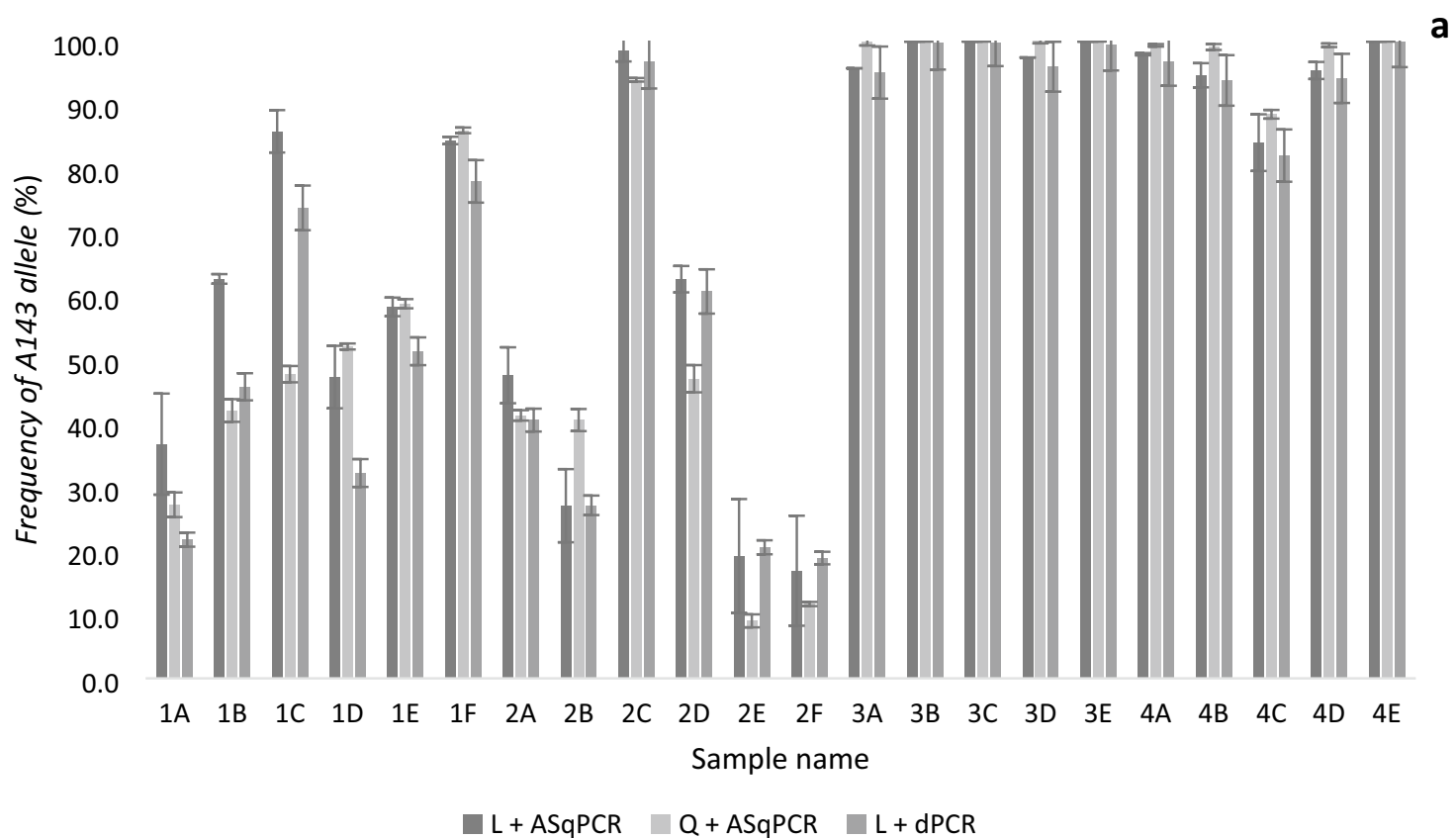

\begin{tabular}{r|r}
100.000 & \\
90.000 & \\
80.000 & \\
70.000 & \\
60.000 & \\
50.000 \\
40.000 \\
30.000 \\
20.000 \\
10.000 \\
0.000
\end{tabular}

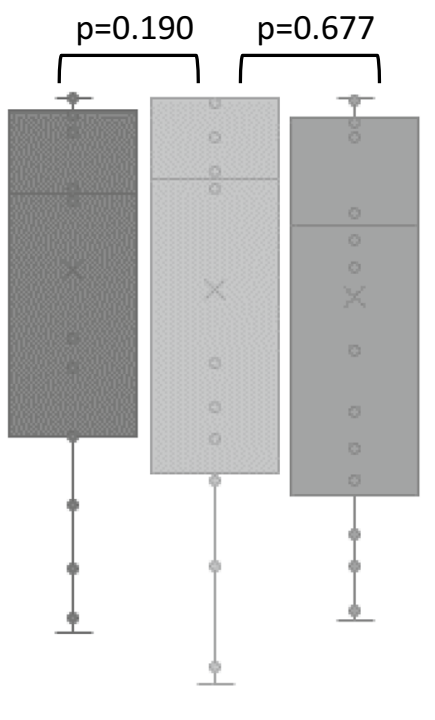

Figure 4. Comparison of $c y t b$ A143 frequency results of samples from Tasmania. Q + ASqPCR - crude DNA + ASqPCR, L + ASqPCR-Lab DNA + ASqPCR, L + dPCR-Lab DNA + dPCR. (a) Individual sample results $1 \mathrm{~A}-1 \mathrm{~F}$ and $2 \mathrm{~A}-2 \mathrm{~F}$ - samples collected from sites 1 and 2 in the Table Cape region; 3A-3E and 4A-4Esamples collected from sites 1 and 2 in the Midlands region. Error bars show standard error of mean of triplicates. (b) Box plots of average results for each analysis type and paired $t$ test. Boxed area represents the inter-quartile range, horizontal line within box represents the median, $\mathrm{x}$ represents the mean.

suggesting a relatively high spread of the mutation in the area (Table 1). Three samples had no detectable levels of the A143 allele.

\section{Discussion and conclusion}

Failure of QoI fungicides to control Bgt in wheat paddocks in the Australian states of Tasmania and Victoria was first reported in $2016^{39}$. Sequencing analysis of the $c y t b$ gene revealed that the well characterised mutation G143A was present in all samples collected from wheat fields in these two Australian states where adequate control of the disease could not be achieved with the use of QoI fungicides (Fig. 1) ${ }^{30}$. As the G143A genotype continues to spread, and possibly emerge, across other wheat growing regions in the world, due to the overexposure to this group of fungicides, the availability of a rapid and robust field-based allele-specific detection method could provide a key advantage for the in-season management of QoI resistance. 


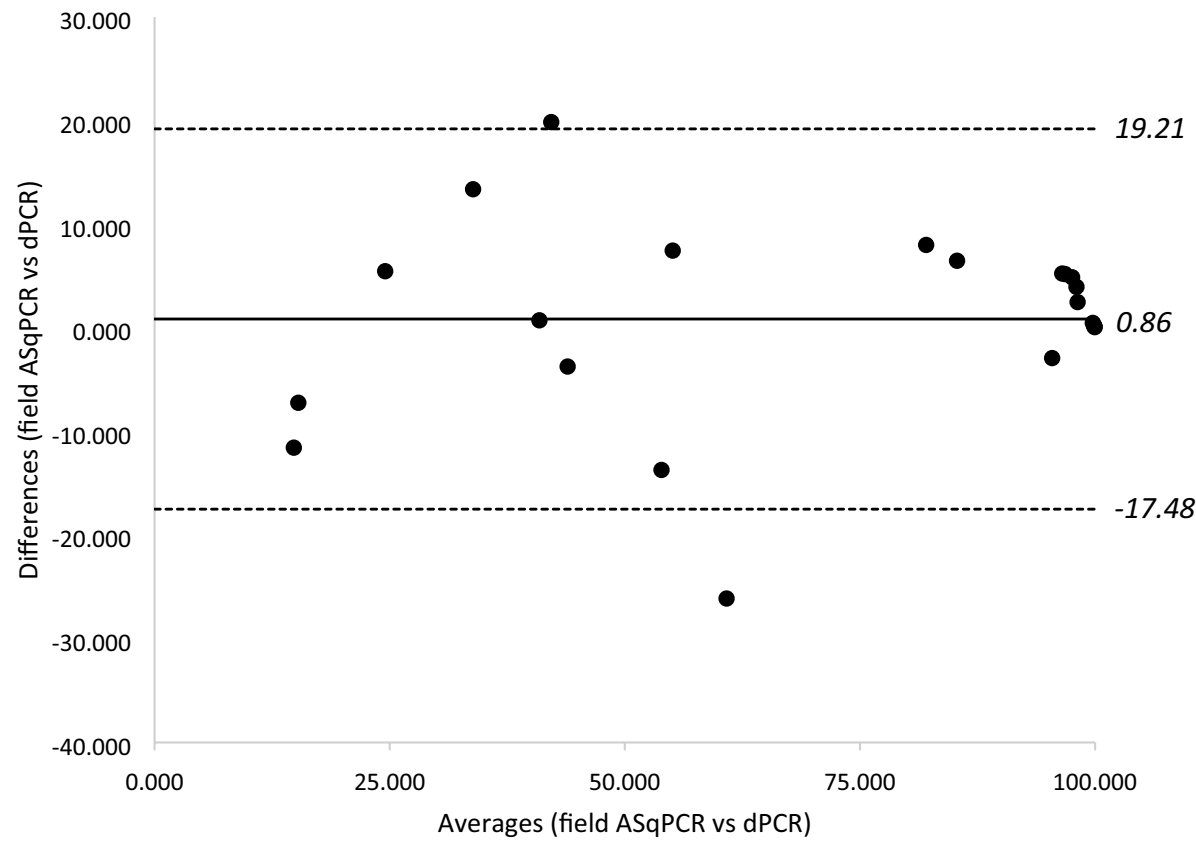

Figure 5. Bland-Altman analysis to check agreement between the results from the field qPCR and lab dPCR $(n=22)$. The bias of 0.86 represented the average difference between the results from the methods and shows that the results from the ASqPCR are overestimated by 0.86 compared to the latter. The upper and lower limits of agreements at 19.21 and -17.48 respectively represent the "bias \pm 1.96 s.d." (s.d. of differences is 9.36 ) $90.1 \%$ of samples are within the limits of agreement.

The detection of fungicide resistance in crop pathogens, previously mostly conducted using bioassays, now largely relies on the use of molecular methods when the genetic mechanism associated with the resistance is $\mathrm{known}^{7}$. For novel field failures, where the target gene is known, capillary sequencing methods are used to determine if any known mutations are the cause $\mathrm{e}^{3,40}$. Once a mutation has been confirmed, PCR and LAMP are commonly used for its detection, whereas for quantification qPCR and more recently digital PCR are used ${ }^{18,26,41-43}$. Except for LAMP, none of the other methods have been used in the field for the detection of fungicide resistance, therefore currently the quantification of mutations associated with fungicide resistance is exclusively laboratory based $^{20}$. We have demonstrated the successful development of a TaqMan probe-based ASqPCR assay, which allows for both the mutant and wild-type alleles to be detected within the same reaction. This has been coupled with a quick, field-friendly DNA extraction method and a robust DNA polymerase to enable the in-field quantification of the QoI resistant mutation G143A in Bgt on a portable and fast qPCR instrument.

The quantification of the CytB G143A mutation in Bgt using ASqPCR was first conducted by Fraaije et al. ${ }^{26}$ using the intercalating dye SYBR 1, with the assay detecting as low as 1 in 10,000 copies of the mutant A143 allele in a sample extraction that contained a mix of fungal and wheat DNA. A qPCR assay developed for the analysis of mutation Y136F in the Cyp51 target site of E. necator had a limit of detection and a limit of quantification of 0.85 and $2.85 \%$, respectively ${ }^{44}$. More recently, Zulak et al. ${ }^{43}$ developed a chip dPCR assay able to quantify mutations S509T and Y136F in the Cyp51 of B. graminis f. sp. hordei infected samples down to $0.2 \%$. In our study, the quantification limit of the field-based G143A ASqPCR assay, when using a DNA extract containing a mixture of both A143 and G143 alleles, and wheat DNA, was 1.67\% (Table 4). However, in samples with homogenous (homoplasmic) genotypes, in a background of wheat DNA, the assay successfully detected seven copies of the G143 or A143 alleles per reaction (Fig. 2b). The latter could be considered as the equivalent to a single spore detection, as each spore has multiple mitochondria and each mitochondrion may have multiple copies of the cytb gene within $\mathrm{it}^{36}$. A laboratory based G143A chip dPCR assay was also developed for comparative purposes. The G143A dPCR assay successfully quantified the cytb A143 allele in a background of G143 and wheat DNA down to a level of $0.33 \%$, whereas its detection limit was estimated at $0.07 \%$ (Fig. 2a; Table 4). In general, dPCR has lower target detection limits and higher reproducibility, than qPCR, the latter due to the use of absolute quantification rather than relying on standard curves ${ }^{43,45,46}$. Due to these properties, dPCR could be considered the gold-standard in molecular detection of fungicide resistant populations.

The assessment of the ASqPCR analysis pipeline under field conditions revealed a marked A143 allele frequency difference between two wheat growing regions of Tasmania (Fig. 4). While the average frequencies of the A143 allele in samples collected at two sites in the Table Cape region remained between $40-50 \%$, the values found in the sites sampled in the Midlands region showed levels above $99 \%$ in nine out of ten analysed samples. The accuracy of the in-field G143A ASqPCR method was validated by comparing the A143 allele frequency results obtained in the field to those from the laboratory using the same method with DNA extracted from the original samples following standard laboratory procedures. The lack of significant differences between the two datasets 
indicated that neither the quick in-field DNA extraction nor the lack of a controlled laboratory environment had an important effect on the outcome of the in-field analysis ( $p$ value $=0.190)$.

The ideal way to directly compare the results from the ASqPCR with dPCR would have been using the same crude extract on both methods. However, when the crude extract was tested on dPCR, no results could be obtained. This could be attributed to the incompatibility of potential inhibitors in the crude extract with the dPCR reagents or with the degradation of the DNA. Therefore, the results from the DNA extracted in the laboratory were used for all further comparison of the analysis methods. To assess the level of sensitivity of the in-field G143A ASqPCR method, we compared the A143 allele frequency results to those obtained from dPCR using Bland-Altman analysis. When this analysis is applied to two testing methods and the results are identical, the average of the differences between paired results should be zero ${ }^{47}$. In this study, the comparison of the two tests indicated that ASqPCR is, on average, overestimating the mutant allele in a sample by just 0.86 units (line of bias; Fig. 5). This is quite remarkable considering that the dPCR method used DNA extracted in the laboratory as opposed to the crude extractions analysed in the field. In our analysis, the limits of agreement, which ranged from 19.21 to -17.48 units, represents $95 \%$ of the range of the differences between the measurements, and eight of the 12 differences greater than $5 \%$ are due to the field analysis showing higher frequencies than the dPCR analysis. The biggest differences were observed in the samples from the Table Cape region where the more moderate A143 levels seemed to display better the overestimating effect (Fig. 4a, 1A-2F). We believe a few factors to be causing this effect, the most likely to be a consequence of the higher sensitivity of the dPCR assay. The DNA analysed by the two methods was extracted from different areas of the same leaf disc and when one allele is very rare, the ratio will have high inherent variability due to stochastic sampling issues. This could also be reflected in a higher variability in the G143A frequency in WPM pustules from samples collected in paddocks where strobilurin resistance is emerging.

Over the past 5 years, the Northern region of Tasmania (Midlands region) had on average greater than six times the area dedicated to growing wheat compared to the North-western region (Table Cape; Cradle Coast)

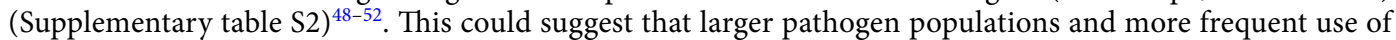
fungicides from the QoI group could be responsible for the higher A143 allele frequency observed in the Midlands region, as the Bgt population would be saturated with strobilurin-resistant mutants. Recently, the G143A mutation has been found at high frequencies in the Yorke Peninsula region of South Australia following new QoI control failure episodes in 2019. The deployment of the in-field G143A ASqPCR method during a field day allowed to correlate higher frequencies of the A143 allele in fields displaying high disease levels after QoI treatment. The results of the analysis were provided on site and the fact that many participants decided to review their chemical control strategies highlights the power of this approach not only as an in-season tool for the management of fungicide resistance, but also as part of more broader extension efforts.

Although there is a lack of specific knowledge about the threshold abundance of the A143 allele which would translate into QoI control failure for the wheat powdery mildew system, studies of this mutation in other organisms have shown that its frequency would have to exceed $60 \%$ before resistance to QoIs becomes apparent ${ }^{53,54}$. This can be used as a guide to demark the threshold for control failure of QoIs in Bgt containing the A143 allele. Future research in this space should assess the level of A143 required for control failure of WPM.

We believe that the ASqPCR conducted in the field is a reliable tool that can be used for rapid and on-site quantification of Bgt mutants carrying the G143A Cytb mutation, and provide valuable information to chemically tackle the disease. An additional advantage of this method is that it can be adapted to detect changes in other genes encoding different fungicide targets. To that effect, a similar assay for the detection of pyrimethanil resistance in the grape pathogen Botrytis cinerea has already been trialled in the field (Harper et al., unpublished).

The technology we describe here substantially increases the speed with which quantitative pathogen diagnosis and fungicide resistance evolution can be measured and delivered to growers. These techniques promise to markedly increase the flexibility of growers to modify fungicide application timing, dose and product choices within a few hours of sampling.

The methodology could be enacted using portable instruments housed in the cab of a vehicle. However, we recognise that the true value of rapid diagnosis will be realised only when it is coupled with reliable advice and product choices. As such, the technology is perhaps best suited to implementation via testing stations located within cropping zones where information from the tests can be coupled with local pathology experience and weather forecasts. This would mean that the treatments used would be tailored to the disease and resistance problems within the crop, which in turn would eliminate the use of unnecessary treatments and reduce the selection pressure that occurs when using unsuitable treatments.

\section{Materials and methods}

Blumeria graminis f. sp. tritici (Bgt) field sample PCR and cytb sequencing. Ten wheat and one barley powdery mildew samples were collected from the states of Western Australia, South Australia, Victoria and Tasmania in 2016 (Table 1). The leaf samples were placed in $15 \mathrm{ml}$ polypropylene tubes filled with $2 \mathrm{ml}$ of $50 \mathrm{mg} \mathrm{L}^{-1}$ benzimidazole water agar ${ }^{55}$, sealed and placed in polystyrene containers with ice packs for express shipment to the laboratory for DNA extraction. For each sample, approximately $3 \mathrm{~cm}$ length of the infected tissue was cut into small pieces and DNA was extracted using a BioSprint 15 instrument and BioSprint 15 DNA plant kit (Qiagen, Australia) according to the manufacturer's protocol. The resulting mix of fungal and wheat DNA was eluted in $1 \times \mathrm{TE}$ buffer $\mathrm{pH} 8.0$ and stored at $-20^{\circ} \mathrm{C}$. The remaining sample was stored at $-20^{\circ} \mathrm{C}$ until further analysis.

The $c y t b$ gene from Bgt was amplified and sequenced using primers WM-Cb-f and WM-Cb-R ${ }^{56}$ (Table 2). Each $100 \mu \mathrm{l}$ PCR reaction contained $5 \mathrm{U}$ of MyTaq DNA polymerase (Bioline, Australia), $20 \mu \mathrm{l} 5 \times$ MyTaq reaction buffer, $0.4 \mu \mathrm{M}$ each primers, 50-100 ng DNA template and water. The thermal-cycling was conducted with 
initial denaturation for $5 \mathrm{~min}$ at $95^{\circ} \mathrm{C}$, followed by 34 cycles of $30 \mathrm{~s}$ at $95^{\circ} \mathrm{C}, 1 \mathrm{~min}$ at $55^{\circ} \mathrm{C}$ and $1 \mathrm{~min}$ at $72{ }^{\circ} \mathrm{C}$, followed by final extension for $10 \mathrm{~min}$ at $72^{\circ} \mathrm{C}$. The PCR products were sequenced by Macrogen (Seoul, South Korea) and the results aligned on Geneious (Biomatters Ltd) with existing Bgt cytb gene reference sequences (GenBank accessions: AF343441.1, AF343442.1) to determine if mutation $g 428 c$, responsible for amino acid substitution G143A, was present.

Design of digital PCR and ASqPCR for the analysis of $\boldsymbol{g} \mathbf{4 2 8 c}$. The digital PCR (dPCR) primers and TaqMan probes used to quantify the presence of mutation $g 428 \mathrm{c}$ in this study were designed as per Zulak et al. ${ }^{43}$ with some modifications (Table 2). The sequence of $c y t b$ flanking $100 \mathrm{bp}$ of the mutation was added to the Custom TaqMan Assay Design Tool, with the species/scale set at 'Non-Human: small scale'. Resulting Bgt cytb wild type (G143 allele; strobilurin-sensitive) and mutant (A143 allele; strobilurin-resistant) primers and probe combinations were ordered as a single-tube mix containing $36 \mu \mathrm{M}$ of each primer and $8 \mu \mathrm{M}$ of each probe (Thermo Fisher Scientific, Australia). The probe targeting A143 allele was labelled with the fluorophore FAM on its 5' end and the probe targeting the G143 allele labelled with VIC. The 3' ends of both probes were labelled with a non-fluorescing quencher (NFQ).

Each $17 \mu \mathrm{l}$ dPCR reaction consisted of $8.5 \mu \mathrm{l}$ QuantStudio 3D Digital PCR $2 \times$ Master Mix (Applied Biosystems, Australia), $0.3 \mu \mathrm{l}$ primer probe pre-mix, and $3 \mu \mathrm{l}$ of 10-20 ng DNA template and made up to $17 \mu \mathrm{l}$ with water. Fifteen $\mu$ l of this reaction was loaded onto a QuantStudio 3D Digital PCR Chip v2 (Applied Biosystems) and cycled on a Geneamp 9700 flat block thermal cycler (Applied Biosystems) under the following conditions: $10 \mathrm{~min}$ at $96^{\circ} \mathrm{C}$, then 40 cycles of $2 \mathrm{~min}$ at $58^{\circ} \mathrm{C}$ and $30 \mathrm{~s}$ at $98^{\circ} \mathrm{C}$, followed by 2 min at $58^{\circ} \mathrm{C}$, and $10 \mathrm{~min}$ at $22^{\circ} \mathrm{C}$. Chips were read on a QuantStudio 3D Digital PCR Instrument (Applied Biosystems). The copy ratio of mutant to wild type allele in each sample was determined using QuantStudio 3D AnalysisSuite software (Applied Biosystems). The DNA from the sequenced samples was tested along with DNA from uninfected wheat leaf, wheat leaf infected with Puccinia triticina and pure P. nodorum DNA. In addition, a dilution series of the DNA from the Goomalling sample (G143 allele, Table 1) and Geelong 1 sample (A143 allele, Table 1) was tested with their respective target probes to determine the detection limits of the assay (A143 abundance: $100 \%, 66.67 \%, 40.50 \%$, $18.18 \%, 6.90 \%, 3.39 \%, 1.68 \%, 0.67 \%, 0.33 \%, 0.17 \%, 0.07 \%$ and $0 \%$; DNA concentration $5000-6000$ copies $^{-1} \mathrm{l}^{-1}$ template). Each test was conducted in triplicate.

The dPCR primers and modified dPCR probes (Sigma-Aldrich, Australia) were used to detect mutation $g 428 \mathrm{c}$ on a magnetic induction cycler (MIC) qPCR instrument (Bio Molecular Systems, Australia). In order to increase probe $T_{m}$ and specificity, three bases in each probe were modified to Locked Nucleic Acids (LNA) (Table 2). In addition, the fluorophore on the probe targeting the G143 allele was changed from VIC to HEX.

Three different qPCR mixes were tested using the Goomalling and Geelong 1 DNA and a DNA sample adjusted to $51 \%$ A143 (Table 1). Each $20 \mu \mathrm{l}$ ASqPCR reaction consisted of $10 \mu \mathrm{l}$ of $2 \times$ mastermix [iQ Multilplex Powermix (Bio-Rad, Australia), Sensifast Probe No-Rox mastermix (Bioline) or ImmoMix ${ }^{\text {Tix }}$ (Bioline)], $0.5 \mu \mathrm{l}$ each of $10 \mu \mathrm{M}$ forward and reverse primers, $0.3 \mu \mathrm{l}$ each of $5 \mu \mathrm{M}$ FAM and HEX probes, $5 \mu$ l of up to $20 \mathrm{ng}$ DNA template and $3.4 \mu \mathrm{l}$ water. The assay was conducted under field conditions using the following parameters: initial denaturation for $5 \mathrm{~min}$ at $95^{\circ} \mathrm{C}$, followed by 40 cycles of $10 \mathrm{~s}$ at $95^{\circ} \mathrm{C}$, and $30 \mathrm{~s}$ at $67{ }^{\circ} \mathrm{C}$ for annealing and extension. This was tested twice with samples run in triplicate in the first experiment and in duplicate in the second. The Sensifast Probe No-Rox mastermix (Bioline) was chosen for future testing. The repeatability of the quantification of the ASqPCR assay, was tested as above with the 51\% A143 DNA sample and its frequency calculated based on standard curves generated using the Goomalling and Geelong 1 DNA. This was tested twice with samples replicated ten times in the first experiment, and six times in the second.

A dilution series similar to that described for dPCR including single and mixture of known allele proportions was tested to determine the detection limits of the assay (A143 abundance: 100\%, 66.67\%, 18.18\%, 6.90\%, 3.39\%, $1.68 \%, 0.67 \%, 0.33 \%, 0.17 \%, 0.07 \%$ and $0 \%$; DNA concentration $5000-6000$ copies $\mu^{-1}$ template). A standard curve was also constructed using a serial dilution of the Goomalling and Geelong 1 DNA to calculate the amount of fungal DNA in the mixtures. The A143 allele frequency was calculated as percentage value using micPCR software v2.8.0 (Bio Molecular Systems). The species specificity of the assay was tested using DNA from plant material infected with closely related pathogens B. graminis f. sp. hordei and E. necator, as well as pure DNA from pathogens sharing the same host; $P$. nodorum and $P$. tritici-repentis.

Development of an in-field allele frequency quantification pipeline. To enable the testing to be conducted in a field setting, a quick DNA extraction protocol was developed as a part of this study. Preliminary testing of this extraction method was conducted using approximately $100 \mathrm{mg}$ of infected plant tissue (Goomaling and Geelong 1) that had been kept at $-20^{\circ} \mathrm{C}$. The material was crushed with a plastic micro pestle in $400 \mu \mathrm{l}$ of the lysis buffer $(0.5 \% \mathrm{w} / \mathrm{v}$ SDS, $1.5 \% \mathrm{w} / \mathrm{v} \mathrm{NaCl})$ until the plant tissue fragmented and turned the solution green. This lysate was then diluted 100-fold in $1 \times$ TE buffer $\mathrm{pH} 8.0$ and $5 \mu$ l used as DNA template in ASqPCR reactions. DNA extraction and its thermal cycling was conducted under field conditions on a lightweight qPCR instrument (Magnetic induction cycler, Bio Molecular Systems) powered using a ITECH200 $12 \mathrm{~V} 200 \mathrm{AH}$ lithium ion battery (iTechWorld, Australia) connected to a $2000 \mathrm{~W} 12 \mathrm{~V}$ pure sine wave inverter (iTechWorld). The cycling run (56 min) was initiated and analysed using the micPCR software on a laptop connected to the qPCR instrument.

Twenty-two wheat powdery mildew samples were collected in 2018 from four locations in the Northern region of Tasmania during a two-day collection trip (Fig. 3; Table 1). On day 1, six samples were collected from each of two fields; each sample, consisting of up to 2 leaf fragments, came from an individual plant chosen at random within a $200 \mathrm{~m}^{2}$ area in their respective fields. The sampling on day 2 was conducted in the same manner, however only 5 samples per field were collected. The samples were maintained in polypropylene tubes 

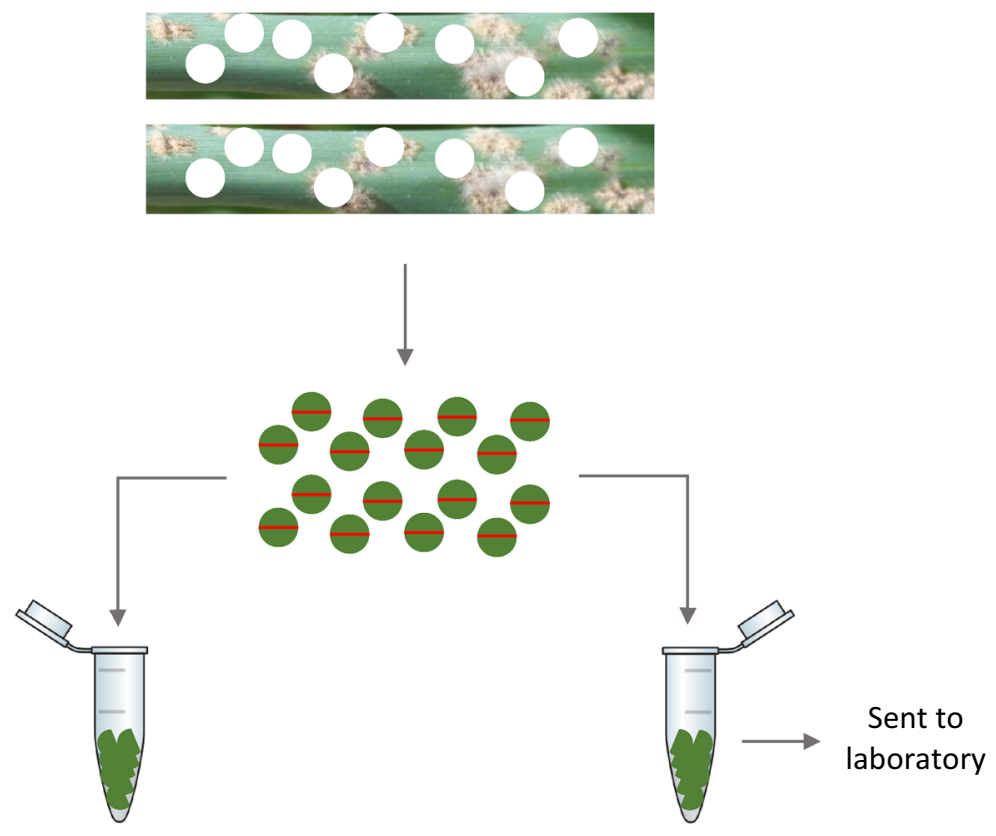

Field ASqPCR

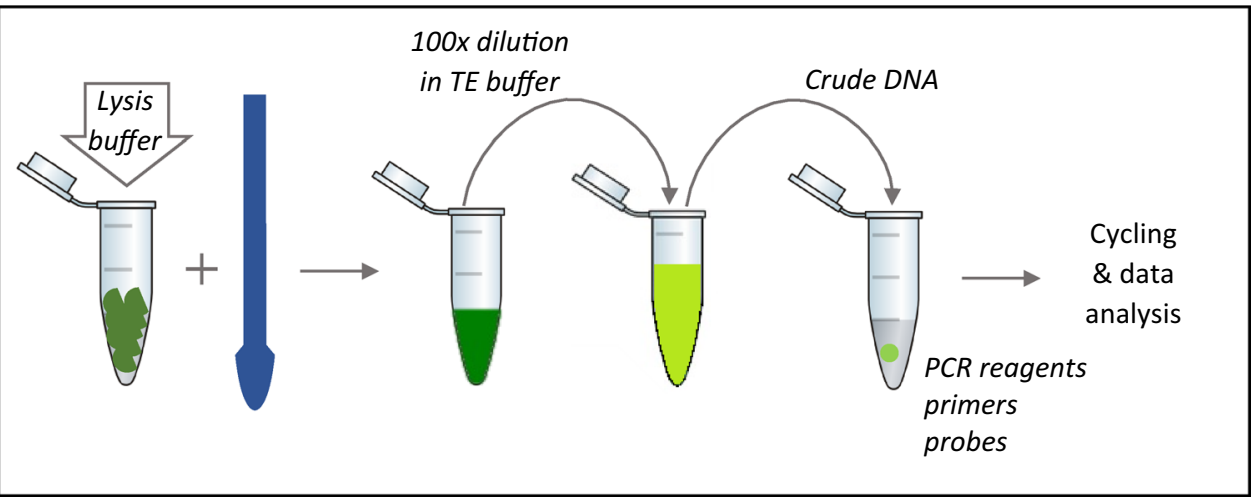

Figure 6. Schematic representation of the procedure followed in the field for the extraction of DNA.

containing benzimidazole agar, as previously described, and stored in a polystyrene box with ice bricks to prevent deterioration prior to processing.

On each day, once sampling was concluded, sixteen $7 \mathrm{~mm}$ discs per infected leaf sample were excised using a WellTech Rapid-Core-7.0 (RapidCore, Australia) disinfected with 70\% v/v ethanol between samples. The discs were halved and separated into two $1.5 \mathrm{ml}$ microfuge tubes to obtain two sets of tubes (1 and 2) with 16 halves each, per sample. The material in set 1 was used for immediate processing and that of set 2 shipped on ice by overnight courier to our laboratory in Perth for dPCR analysis (Fig. 6). Samples in set 1 were processed using the quick DNA extraction method described earlier. The ASqPCR reactions were set-up as described above and $5 \mu \mathrm{l}$ of the DNA extract was used directly in the reaction mix. Each sample was tested in triplicate and the amount of fungal DNA was measured using a standard curve constructed from Goomalling and Geelong 1 DNA of known concentrations amplified alongside the samples. The amount of mutant allele in each sample was reported as a percent value. Remaining crude DNA was shipped with the tubes from set 2 for subsequent dPCR analysis in the laboratory.

In-lab sample processing. Upon receiving set 2 in the laboratory, tissue was frozen in liquid nitrogen then crushed to a fine powder using a $2 \mathrm{~mm}$ stainless steel ball bearing in a Retsch mixer mill MM400 (Retsch, Germany), followed by DNA extraction with a Biosprint Plant DNA 15 kit (Qiagen), as per manufacturer's instructions. The DNA was eluted in $200 \mu \mathrm{l}$ of $1 \times \mathrm{TE}$ buffer and tested using both dPCR and ASqPCR in the same manner as above. Any sample that fell outside the 200-2000 copy range on the dPCR was diluted/concentrated and re-tested as required. 
Statistical analysis of dPCR and ASqPCR results. The results from all three methods were simultaneously compared using a box-plot as well as comparing paired results using a two tailed t test on Microsoft Excel. Additionally, the results of the dPCR and field ASqPCR analyses were compared using SigmaPlot v13 (Systat Software, San Jose, CA). A Bland-Altman analysis, also known as the Tukey's mean difference test was conducted. The Bland-Altman plot was constructed by plotting the difference between the paired data points (method 1 minus method 2) on the $\mathrm{y}$-axis and the mean of the paired data points on the $\mathrm{x}$-axis ${ }^{47}$. The mean of the difference between the pairs represents the bias i.e. whether the method 1 is overestimating (positive bias) or underestimating (negative bias) compared to method 2. The upper and lower limits of confidence are calculated as the mean (bias) \pm 1.96 standard deviation of the differences.

In-field application of the ASqPCR pipeline for the detection of $c y t b$ mutation $g 428 c$. In October 2019, suspected strobilurin-resistant wheat powdery mildew samples $(n=12)$ collected from different farms and brought by growers attending an industry field day at Northern Yorke Peninsula (South Australia), were processed in-field (Table 1). The tissue was not excised using the coring tool, rather cut into small fragments using scissors and forceps disinfected with $70 \% \mathrm{v} / \mathrm{v}$ ethanol between samples. Each sample was added up to the $100 \mu \mathrm{l}$ graduation in $1.5 \mathrm{ml}$ microfuge tubes. This was followed by a quick DNA extraction and ASqPCR assay on the MIC qPCR instrument (Bio Molecular Systems) as detailed above, and mutant frequency results communicated to the growers upon assay completion.

Received: 9 September 2020; Accepted: 8 February 2021

Published online: 25 February 2021

\section{References}

1. Brent, K. J. Fungicide resistance in crop pathogens: How can it be managed? FRAC Monogr. (1995).

2. Russell, P. E. Fungicide resistance: Occurrence and management. J. Agric. Sci. 124, 317-323 (1995).

3. Hobbelen, P. H. F., Paveley, N. D. \& van den Bosch, F. The emergence of resistance to fungicides. PLoS ONE 9, e91910 (2014),

4. Lucas, J. A., Hawkins, N. J. \& Fraaije, B. A. The evolution of fungicide resistance, chapter 2. In Advances in Applied Microbiology Vol. 90 (eds Sariaslani, S. \& Gadd, G. M.) 29-92 (Academic Press, New York, 2015).

5. Brent, K. J. \& Hollomon, D. W. Fungicide Resistance: The Assessment of Risk (Global Crop Protection Federation Brussels, Belgium, 1998).

6. Leadbeater, A. J. Plant health management: Fungicides and antibiotics. In Encyclopedia of Agriculture and Food Systems (ed. Van Alfen, N. K.) 408-424 (Academic Press, New York, 2014). https://doi.org/10.1016/B978-0-444-52512-3.00179-0.

7. Hollomon, D. W. Fungicide resistance: 40 years on and still a major problem. In Fungicide Resistance in Plant Pathogens: Principles and a Guide to Practical Management (eds Ishii, H. \& Hollomon, D. W.) 3-11 (Springer, Tokyo, 2015). https://doi.org/10.1007/ 978-4-431-55642-8_1.

8. De Miccolis Angelini, R. M., Pollastro, S. \& Faretra, F. Genetics of fungicide resistance. In Fungicide resistance in plant pathogens: Principles and a guide to practical management (eds Ishii, H. \& Hollomon, D. W.) 13-34 (Springer, Tokyo, 2015).

9. Luck, J. E. \& Gillings, M. R. Rapid identification of benomyl resistant strains of Botrytis cinerea using the polymerase chain reaction. Mycol. Res. 99, 1483-1488 (1995).

10. R4P Network. Trends and challenges in pesticide resistance detection. Trends Plant Sci. 21, 834-853 (2016).

11. Tsao, P. H. Selective media for isolation of pathogenic fungi. Annu. Rev. Phytopathol. 8, 157-186 (1970).

12. Allen, T. R., Millar, T., Berch, S. M. \& Berbee, M. L. Culturing and direct DNA extraction find different fungi from the same ericoid mycorrhizal roots. New Phytol. 160, 255-272 (2003).

13. Notomi, T. et al. Loop-mediated isothermal amplification of DNA. Nucleic Acids Res. 28, E63 (2000).

14. Nagamine, K., Hase, T. \& Notomi, T. Accelerated reaction by loop-mediated isothermal amplification using loop primers. Mol. Cell Probes 16, 223-229 (2002).

15. Fukuta, S., Mizukami, Y., Ishida, A. \& Kanbe, M. Development of loop-mediated isothermal amplification (LAMP)-based SNP markers for shelf-life in melon (Cucumismelo L.). J. Appl. Genet. 47, 303-308 (2006).

16. Kogovšek, P. et al. LAMP assay and rapid sample preparation method for on-site detection of flavescence dorée phytoplasma in grapevine. Plant Pathol. 64, 286-296 (2015).

17. Pan, L., Li, J., Zhang, W. N. \& Dong, L. Detection of the I1781L mutation in fenoxaprop-p-ethyl-resistant American sloughgrass (Beckmanniasyzigachne Steud.), based on the loop-mediated isothermal amplification method. Pest Manag. Sci. 71, 123-130 (2015).

18. Duan, Y. et al. Development and application of loop-mediated isothermal amplification for detection of the F167Y mutation of carbendazim-resistant isolates in Fusarium graminearum. Sci. Rep. 4, 7094 (2014).

19. Harrison, C., Tomlinson, J., Ostoja-Starzewska, S. \& Boonham, N. Evaluation and validation of a loop-mediated isothermal amplification test kit for detection of Hymenoscyphusfraxineus. Eur. J. Plant Pathol. 149, 253-259 (2017).

20. Hu, X. R., Dai, D. J., Wang, H. D. \& Zhang, C. Q. Rapid on-site evaluation of the development of resistance to quinone outside inhibitors in Botrytiscinerea. Sci. Rep. 7, 13861 (2017).

21. Wu, J. Y., Hu, X. R. \& Zhang, C. Q. Molecular detection of QoI resistance in Colletotrichumgloeosporioides causing strawberry anthracnose based on loop-mediated isothermal amplification assay. Plant Dis. 103, 1319-1325 (2019).

22. Suleman, E., Mtshali, M. S. \& Lane, E. Investigation of false positives associated with loop-mediated isothermal amplification assays for detection of Toxoplasmagondii in archived tissue samples of captive felids. J. Vet. Diagn. Investig. Off. Publ. Am. Assoc. Vet. Lab. Diagn. Inc. 28, 536-542 (2016).

23. Hardinge, P. \& Murray, J. A. H. Reduced false positives and improved reporting of loop-mediated isothermal amplification using quenched fluorescent primers. Sci. Rep. 9, 7400 (2019).

24. van den Bosch, F., Oliver, R., van den Berg, F. \& Paveley, N. Governing principles can guide fungicide-resistance management tactics. Annu. Rev. Phytopathol. 52, 175-195 (2014).

25. Ugozzoli, L. \& Wallace, R. B. Allele-specific polymerase chain reaction. Methods 2, $42-48$ (1991).

26. Fraaije, B. A., Butters, J. A., Coelho, J. M., Jones, D. R. \& Hollomon, D. W. Following the dynamics of strobilurin resistance in Blumeriagraminis $\mathrm{f}$. sp. tritici using quantitative allele-specific real-time PCR measurements with the fluorescent dye SYBR Green I. Plant Pathol. 51, 45-54 (2002).

27. McCartney, H. A., Foster, S. J., Fraaije, B. A. \& Ward, E. Molecular diagnostics for fungal plant pathogens. Pest Manag. Sci. 59, 129-142 (2003). 
28. Selim, S. Allele-specific real-time PCR for quantification and discrimination of sterol 14a-demethylation-inhibitor-resistant genotypes of Mycosphaerellagraminicola. J. Plant Pathol. 91, 391-400 (2009).

29. Robinson, H. L., Ridout, C. J., Sierotzki, H., Gisi, U. \& Brown, J. K. M. Isogamous, hermaphroditic inheritance of mitochondrionencoded resistance to Qo inhibitor fungicides in Blumeriagraminis f. sp. tritici. Fungal Genet. Biol. 36, 98-106 (2002).

30. Sierotzki, H., Wullschleger, J. \& Gisi, U. Point mutation in cytochrome b gene conferring resistance to strobilurin fungicides in Erysiphe graminis f. sp. tritici field isolates. Pestic. Biochem. Physiol. 68, 107-112 (2000).

31. Chin, K. M., Chavaillaz, D., Kaesbohrer, M., Staub, T. \& Felsenstein, F. G. Characterizing resistance risk of Erysiphegraminis f. sp. tritici to strobilurins. Crop Prot. 20, 87-96 (2001).

32. Sauter, H., Steglich, W. \& Anke, T. Strobilurins: Evolution of a new class of active substances. Angew. Chem. Int. Ed. Engl. 38, 1328-1349 (1999).

33. Fraaije, B. A., Butters, J. A. \& Hollomon, D. W. In planta genotyping of Erysiphe graminis f. sp. tritici isolates for strobilurinresistance using a fluorometric allele-specific PCR assay, 401-406 (2000).

34. Leadbeater, A. Resistance risk to QoI fungicides and anti-resistance strategies. In Fungicide Resistance in Crop Protection: Risk and Management (ed. Thind, T. S.) 144-154 (CABI, Wallingford, 2012). https://doi.org/10.1079/9781845939052.0000.

35. Mair, W. et al. Proposal for a unified nomenclature for target-site mutations associated with resistance to fungicides. Pest Manag. Sci. 72, 1449-1459 (2016).

36. Bäumler, S. et al. Evaluation of Erysiphegraminis f. sp. tritici field isolates for resistance to strobilurin fungicides with different SNP detection systems. Pest Manag. Sci. 59, 310-314 (2003).

37. ABARES. Australian crop report. Aust. Bur. Agric. Resour. Econ. Sci. Canberra (2020).

38. Murray, G. M. \& Brennan, J. P. Estimating disease losses to the Australian wheat industry. Australas. Plant Pathol. 38, 558-570 (2009).

39. Watt, S. \& Novelli, P. Fungicide resistance discovery calls for urgent action. GRDC news and media release https://grdc.com.au/ news-and-media/news-and-media-releases/national/2017/03/fungicide-resistance-discovery-calls-for-urgent-action (2017).

40. Mair, W. J. et al. Demethylase inhibitor fungicide resistance in Pyrenophorateres f. sp. teres associated with target site modification and inducible overexpression of Cyp51. Front. Microbiol. 7, 1279 (2016).

41. Vela-Corcía, D., Bellón-Gómez, D., López-Ruiz, F., Torés, J. A. \& Pérez-García, A. The Podosphaerafusca TUB2 gene, a molecular 'Swiss Army knife' with multiple applications inpowdery mildew research. Fungal Biol. 118, 228-241 (2014).

42. Hollomon, D. W. \& Ishii, H. Monitoring resistance using molecular methods. In Fungicide Resistance in Plant Pathogens: Principles and a Guide to Practical Management (eds Ishii, H. \& Hollomon, D. W.) 295-309 (Springer, Tokyo, 2015). https://doi.org/10.1007/ 978-4-431-55642-8_18.

43. Zulak, K. G., Cox, B. A., Tucker, M. A., Oliver, R. P. \& Lopez-Ruiz, F. J. Improved detection and monitoring of fungicide resistance in Blumeriagraminis f. sp. hordei with high-throughput genotype quantification by digital PCR. Front. Microbiol. 9, 706 (2018).

44. Dufour, M.-C., Fontaine, S., Montarry, J. \& Corio-Costet, M.-F. Assessment of fungicide resistance and pathogen diversity in Erysiphe necator using quantitative real-time PCR assays. Pest Manag. Sci. 67, 60-69 (2011).

45. Cao, L. et al. Advances in digital polymerase chain reaction (dPCR) and its emerging biomedical applications. Biosens. Bioelectron. 90, 459-474 (2017).

46. Quan, P.-L., Sauzade, M. \& Brouzes, E. dPCR: A technology review. Sensors (Basel) 18, 1271 (2018).

47. Bland, J. M. \& Altman, D. G. Statistical methods for assessing agreement between two methods of clinical measurement. Lancet 327, 307-310 (1986)

48. Australian Bureau of Statistics. Agricultural Commodities, Australia, 2014-15, 'Table 07. Agricultural commodities, state and NRM region-Tasmania-2014-15'. Data cube Excel spreadsheet cat. no. 7121.0 (2016).

49. Australian Bureau of Statistics. Agricultural Commodities, Australia, 2015-16, 'Table 07. Agricultural commodities, state and NRM region-Tasmania-2015-16. Data cube Excel spreadsheet cat. no. 7121.0 (2017).

50. Australian Bureau of Statistics. Agricultural Commodities, Australia, 2016-17, 'Table 07. Agricultural commodities, state and NRM region-Tasmania-2016-17. Data cube Excel spreadsheet cat. no. 7121.0 (2018).

51. Australian Bureau of Statistics. Agricultural Commodities, Australia, 2017-18, 'Table 07. Agricultural commodities, state and NRM region-Tasmania-2017-18'. Data cube Excel spreadsheet cat. no. 7121.0 (2019).

52. Australian Bureau of Statistics. Agricultural Commodities, Australia, 2018-19, 'Table 07. Agricultural commodities, state and NRM region-Tasmania-2018-19'. Data cube Excel spreadsheet cat. no. 7121.0 (2020).

53. Villani, S. M. \& Cox, K. D. Heteroplasmy of the cytochrome b gene in Venturiainaequalis and its involvement in quantitative and practical resistance to trifloxystrobin. Phytopathology 104, 945-953 (2014).

54. Vielba-Fernández, A. et al. Heteroplasmy for the cytochrome b gene in Podosphaeraxanthii and its role in resistance to QoI fungicides in Spain. Plant Dis. 102, 1599-1605 (2018).

55. Heun, M. Virulence frequencies influenced by host resistance in the host-pathogen system wheat-powdery mildew. J. Phytopathol. 118, 363-366 (1987).

56. Bäumler, S., Felsenstein, F. G. \& Schwarz, G. CAPS and DHPLC analysis of a single nucleotide polymorphism in the cytochrome $\mathrm{b}$ gene conferring resistance to strobilurins in field isolates of Blumeriagramims f. sp. hordei. J. Phytopathol. 151, 149-152 (2003).

\section{Acknowledgements}

This study was supported by the Centre for Crop and Disease Management, a co-investment of Curtin University and the Australian grains industry through the Grains Research and Development Corporation (research grant CUR00023). The authors wish to thank Rose Kristoffersen and Wesley Mair for the technical assistance during the Tasmanian and South Australian field trips, respectively. They also wish to thank Dr. Ayalsew Zerihun for providing assistance with the Bland-Altman analysis, Foundation for Arable Research (FAR) for sample contribution and, Sam Trengove for coordinating sample submission at the field day in South Australia.

\section{Author contributions}

F.L.-R. designed the project. K.D. and R.O. contributed to the conception of the work. K.D. and B.C. performed the analysis and interpretation of data. K.D. and F.L.-R. wrote the main manuscript and KD prepared Fig. 6. All authors reviewed the manuscript.

\section{Competing interests}

The authors declare no competing interests.

\section{Additional information}

Supplementary Information The online version contains supplementary material available at https://doi.org/ 10.1038/s41598-021-83981-9. 
Correspondence and requests for materials should be addressed to F.J.L.-R.

Reprints and permissions information is available at www.nature.com/reprints.

Publisher's note Springer Nature remains neutral with regard to jurisdictional claims in published maps and institutional affiliations.

(c) (i) Open Access This article is licensed under a Creative Commons Attribution 4.0 International cc) License, which permits use, sharing, adaptation, distribution and reproduction in any medium or format, as long as you give appropriate credit to the original author(s) and the source, provide a link to the Creative Commons licence, and indicate if changes were made. The images or other third party material in this article are included in the article's Creative Commons licence, unless indicated otherwise in a credit line to the material. If material is not included in the article's Creative Commons licence and your intended use is not permitted by statutory regulation or exceeds the permitted use, you will need to obtain permission directly from the copyright holder. To view a copy of this licence, visit http://creativecommons.org/licenses/by/4.0/.

(c) Crown 2021 